\title{
The formation of polycomplexes of poly(methyl vinyl ether- $C O$-maleic anhydride) and bovine serum albumin in the presence of copper ions
}

\author{
Mesut Karahan ${ }^{1 *}$, Zeynep Mustafaeva², Cemal Özeroğlu ${ }^{3}$ \\ ${ }^{1}$ Üsküdar University, Faculty of Engineering and Natural Sciences, Department of Bioengineering, \\ 34662 Uskudar-Istanbul, Turkey \\ 2 Yildiz Technical University, Faculty of Chemical and Metallurgical Engineering, Department of Bioengineering, \\ 34220 Esenler-Istanbul Turkey \\ ${ }^{3}$ Istanbul University, Faculty of Engineering, Department of Chemistry, 34320 Avclar-Istanbul Turkey \\ "Corresponding author: e-mail: mesut.karahan@uskudar.edu.tr
}

\begin{abstract}
The binary and ternary complex formations of poly(methyl vinyl ether-co-maleic anhydride) (PMVEMA) with copper ions and with bovine serum albumin (BSA) in the presence of copper ions in phosphate buffer solution at $\mathrm{pH}=7$ were examined by the techniques of UV-visible, fluorescence, dynamic light scattering, atomic force microscopy measurements. In the formation of binary complexes of PMVEMA-Cu(II), the addition of copper ions to the solution of PMVEMA in phosphate buffer solution at $\mathrm{pH}=7$ forms homogeneous solutions when the molar ratio of $\mathrm{Cu}$ (II)/MVEMA is 0.5 . Then the formations of ternary complexes of PMVEMA-Cu(II)-BSA were examined. Study analysis revealed that the toxicities of polymer-metal and polymer-metal-protein mixture solutions depend on the nature and ratio of components in mixtures.
\end{abstract}

Keywords: polyelectrolyte, bovine serum albumin, copper ions, metal complexes, biological processes, biomaterials.

\section{INTRODUCTION}

Investigation of water soluble and insoluble complexes of polymer with protein in the presence of metal ions has important applications in various areas ${ }^{1-14}$. In recent studies, it has been shown that metal (M) ions $\left(\mathrm{Cu}^{2+}\right.$, $\mathrm{Zn}^{2+}, \mathrm{Fe}^{2+}$ ) which are complexed with functional polymers have an important role in biological processes ${ }^{2,15-23}$.

Relevant studies revealed that nitrogen- and carboxyl-containing PE such as poly(acrylic acid) (PAA), poly(vinyl pyridine), poly( $\mathrm{N}$-isopropyl acrylamide) and PMVEMA have been performed for the formation of ternary polymer metal complexes (PMC) with protein such as bovine serum albumin (BSA), human serum albumin, ovalbumin and bovine $\gamma$-globulin. The contact of proteins with polyelectrolyte (PE) is located at interface. Solubility of polycomplexes depends on the nature of proteins and correlates with their isoelectric point. In these systems, metal ions generally promote two effects: (1) the binding of polyelectrolite to protein molecules and (2) inter molecular aggregation of polycomplex particles. The solubility, composition, and stability of these polycomplexes depend on $\mathrm{pH}$, metal/ $\mathrm{PE}$, and protein/PE ratios. Some of these polycomplexes reveal strong immunogenecity and provide a high level of immunological protection ${ }^{2,24-27}$.

Synthetic PE applications have been found to increase immunoresponse to the immunizing agent and to produce an adjuvant effect ${ }^{17,18,28,29}$. PE used as carrier in ternary complexes is firmly linked to microbial and viral antigens to form a stable complex (i.e., increased by several orders of magnitude the immune responsiveness of the organism but also afforded effective immune protection), which allows an avenue to manufacture artificial vaccines against yet uncontrolled infections ${ }^{2}$. Such systems include complexes stabilized by cooperative electrostatic and hydrophobic interactions between the fragments of $\mathrm{PE}$ and antigen molecules and conjugates in which the functional groups of the components are linked by covalent bonds.
In those cases, where PE macromolecules do not contain the corresponding electrostatic or hydrophobic groups for antigen binding, it is necessary to modify the carrier polymer, which can give rise to changes in its effect(s) upon biological systems.

A relatively good technique involves the use of $\mathrm{M}$ ions compounds as means of activating the support surface and allowing direct proteins coupling without prior activated support, through formation of chelate ${ }^{30}$. Recent findings showed the existence of a ternary complex between proteins, $\mathrm{Cu}(\mathrm{II})$ ions and amino acid ${ }^{31}$.

Recently, fluorescence techniques were used to study protein-polyelectrolyte complexation ${ }^{2,16,32,33}$. From the fluorescent emission shift of tryptophan residues in proteins, it is possible to localize the interaction between proteins and PE at certain protein domains ${ }^{25}$. The BSA molecule is known to contain two tryptophan (Trp) residues. One of them is located on the bottom of hydrophobic cleft between domains 1 and 3 whereas the other is on the surface of the molecule ${ }^{34,35}$. Considering that $\mathrm{Cu}(\mathrm{II})$ ions are efficient fluorescence quenchers, one may expect that fluorescence study of PE binding to BSA in the presence of $\mathrm{Cu}(\mathrm{II})$ ions can provide valuable information regarding the structural features of soluble ternary polycomplexes ${ }^{25,34}$.

In present study, the interaction between PMVEMA and BSA in the presence of M ions in aqueous solution was analyzed by using UV-visible, dynamic light scattering (DLS), atomic force microscope (AFM) and fluorescence measurements. More stable water soluble binary complexes were obtained, when the ratio $\mathrm{n}_{\mathrm{Cu}(\mathrm{III})} /$ $\mathrm{n}_{\text {MVEMA }} \leq 0.5$. Water soluble and insoluble polycomplexes have been obtained depending on different condition of $\mathrm{n}_{\mathrm{Cu}(\mathrm{III})} / \mathrm{n}_{\text {MVEMA }}$ with and without BSA concentration and the $n_{\text {BSA }} / n_{\text {PMVEMA }}$ at different molar ratios of $\mathrm{Cu}(\mathrm{II}) /$ MVEMA. Technique of atomic force microscopy was used to indicate the structure of ternary complexes at nano-scale form. The toxicities of solution of the polymer-metal and polymer-metal-protein mixtures were 
determined, depending on nature of pure components and the ratio of components in the mixtures.

\section{MATERIALS AND METHODS}

\section{Materials}

(PMVEMA) (Gantiez AN 139 BF) was supplied from ISP Europe and used without further treatment. Bovine serum albumin $(\mathrm{BSA})(\mathrm{Mw}=70 \mathrm{kDa}, \mathrm{pI}=4.9)$ was purchased from Sigma chemical company (St. Louis, USA), other chemicals such as copper sulfate pentahydrate $\left(\mathrm{CuSO}_{4}, 5 \mathrm{H}_{2} \mathrm{O}\right.$, Merck), sodium dihydrogen phosphate $\left(\mathrm{NaH}_{2} \mathrm{PO}_{4}\right.$, Reiadel de Haën), disodium hydrogen phosphate $\left(\mathrm{Na}_{2} \mathrm{HPO}_{4}\right.$, Fluka), which were used without further treatment. Ultra pure water was obtained from Millipare Milli-Q gradient system. The solutions of PMVEMA ( $3 \mathrm{~g} / \mathrm{L})$ used in this study were prepared in phosphate buffer solutions of $\mathrm{pH}=7$ in cold room $\left(5^{\circ} \mathrm{C}\right)$ with stirring over 12 hours. The molecular weight of PMVEMA in phosphate buffer solution at $\mathrm{pH}=7$ was found as $\overline{\mathrm{M}}_{\mathrm{w}}=41 \mathrm{kDa}$ by the measurement technique of gel permeation chromatography. Copper sulfate and BSA were dissolved in ultra pure water and $\mathrm{pH}$ of solutions was adjusted to $\mathrm{pH}=7$ by adding of $0.1 \mathrm{~N}$ $\mathrm{NaOH}$ solution as needed.

\section{Preparation of polymer-Cu(II) and polymer-Cu(II)-BSA complexes}

In order to produce polymer metal complexes, copper sulfate pentahydrate at different concentrations and PMVEMA at constant concentration $(3 \mathrm{~g} / \mathrm{L})$ were prepared. The molar ratios of $\mathrm{Cu}(\mathrm{II}) / \mathrm{MVEMA}$ were taken as $0.1,0.2,0.3,0.4,0.5,1.0,1.5$, and 2.0. The total volume of the obtained solution $10 \mathrm{~mL}$ and the $\mathrm{pH}$ of solution was adjusted to 7 by using $1 \mathrm{~N} \mathrm{NaOH}$ solution prepared in ultra pure water.

To prepare the ternary mixtures of PMVEMA-Cu(II)-BSA, each of solutions containing molar ratios of $\mathrm{Cu}(\mathrm{II}) /$ MVEMA $=0.1,0.2,0.3,0.4,0.5,1.0,1.5$, and 2.0 was mixed with the required amount of BSA as weight $(\mathrm{mg})$. The molar ratios of BSA to PMVEMA were taken as $0.5,1.0,1.5,3.0,2.5$ and 3.0 and the total volume of each solution was kept constant as $10 \mathrm{~mL}$. The $\mathrm{pH}$ of each solution was adjusted to 7 using $1 \mathrm{~N} \mathrm{NaOH}$ solution.

\section{METHODS}

\section{Viscosity}

The viscosity measurements were performed at a constant temperature of $25^{\circ} \mathrm{C}$ with an Ubbelohde automatic viscometer (Schott Gerate, Berlin, Germany).

\section{Fluorescence measurements}

Quanta Master spectrofluorometer (Photon Technology International, Canada) operating in quanta counting mode was used to obtain the fluorescence emission spectra. The slits for the excitation and emission monochromators were set to 2 or $3 \mathrm{~nm}$. The excitation wavelength was $280 \mathrm{~nm}$. We characterized them through measurements of the maximum wavelength of the fluorescence emission spectrum $\left(\lambda_{\max }\right)$, and the fluorescence intensity (I).

\section{Dynamic light scattering method}

Photon correlation spectroscopy with a Zetasizer Nano ZS instrument equipped with $4.0 \mathrm{mV} \mathrm{He-Ne} \mathrm{laser} \mathrm{at} \mathrm{a}$ wavelength $633 \mathrm{~nm}$ at a temperature $25^{\circ} \mathrm{C}$ and manufactured by Malvern Instruments, UK was used to examine the properties of the average size and size distribution of protein, polymer and complexes of protein-metalpolymer. Before DLS measurement, each solution was filtered with $0.2 \mu \mathrm{m}$ RC-membrane Sartorius filters to remove the impurities from the solutions.

\section{Measurements by atomic force microscopy}

Atomic force microscopy (Shimadzu Scanning Probe Microscope SPM-9600) is a very high-resolution type of scanning probe microscopy with demonstrated resolution on the order of fractions of a nanometer more than 1000 times better than the optical diffraction limit. The AFM is one of the foremost tools for imagining, measuring and manipulating matter at the nano-scale. The information is gathered by "feeling" the surface with a mechanical probe. Piezoelectric elements that facilitate tiny but accurate and precise movements on commend enable very precise scanning ${ }^{\mathbf{3 6}, 37}$.

Technical applications appear to be abundant because the AFM can make three dimensional quantitative measurements with high resolution and on a wide variety of samples than virtually any other technique ${ }^{37-41}$. All samples were prepared in ultrapure water [PMVEMA $(0.15 \mu \mathrm{g} / 1 \mathrm{ml})$, BSA $(0.15 \mu \mathrm{g} / 1 \mathrm{ml})$ and PMVEMA-Cu(II)-BSA (BSA $0.15 \mu \mathrm{g} / 1 \mathrm{ml})$ ].

\section{Preparation of Thiazolyl Blue Tetrazolium Bromide Solution (MTT)}

Solution prepared by dissolving $50 \mathrm{mg}$ Thiazolyl blue tetrazolium bromide powder (Sigma M5655) in $5 \mathrm{~mL}$ phosphate buffered saline was filtered through filter with respective pore sizes, $0.45 \mu \mathrm{L}$ and $0.22 \mu \mathrm{L}$ (Sartorius MiniSart RC filter).

Investigation of Toxic Effects of Polyelectrolyte, Polyelectrolyte-Copper and Polyelectrolyte-Copper-BSA complexes on L929 cells with MTT Method

L929 cells (with $10^{4}$ cell $/ \mathrm{mL}$ concentration) were seeded on ninety-six-well polystyrene plates. After cell adhesion on the wells, $10 \mu \mathrm{L}$ of polyelectrolyte, polyelectrolyte-copper, polyelectrolyte-copper-protein solution were added on the cells adhered to the wells. Ultra-pure water was used as the control group. Cells were incubated at $37^{\circ} \mathrm{C}$ with humid air for 48 hours. And then $10 \mathrm{mg} /$ $\mathrm{mL}$ of MTT solution was added to each well and incubated for 4 hours. $100 \mu \mathrm{L}$ of MTT stop solution was added and incubated at room temperature for 30 min. The same procedure was used (i.e., without cells) to evaluate interaction of the polymer conjugates with medium. Optical density was measured at $570 \mathrm{~nm}$ wavelength with micro plate photometer measuring device ${ }^{\mathbf{1 5}}$.

\section{RESULTS AND DISCUSSION}

\section{Formation of binary polymer-metal complexes}

The addition of different amount of copper ions to PMVEMA solutions gives homogeneous solution at $\mathrm{pH}=7$. With increasing of the molar ratios of $\mathrm{Cu}(\mathrm{II}) /$ 
MVEMA, the solubility of binary complexes decreased and insoluble complexes took place. This was confirmed by UV-visible, gravimetric, viscometric and DLS measurements.

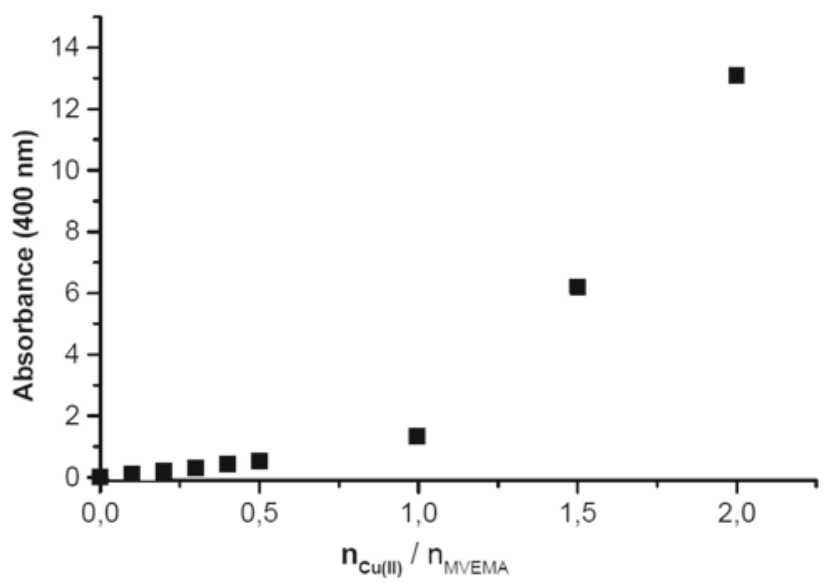

Figure 1. The dependence of optical density at $400 \mathrm{~nm}\left(\mathrm{~A}_{400}\right)$ on the molar ratio of $\mathrm{Cu}(\mathrm{II}) / \mathrm{MVEMA}$ for the formation of binary complexes of PMVEMA-Cu(II) prepared at phosphate buffer solution at $\mathrm{pH}=7$. The molar ratio of $\mathrm{Cu}(\mathrm{II}) / \mathrm{MVEMA}=0.1,0.2,0.3,0.4,0.5,1.0$, 1.5 and 2.0. The total volume of solution is $10 \mathrm{~mL}$. $\mathrm{C}_{\text {PMVEMA }}=3 \mathrm{~g} / \mathrm{L}$

The dependence of optical density at $400 \mathrm{~nm}$ is illustrated in Figure 1. As can be seen from Figure 1, the absorbance values at $400 \mathrm{~nm}$ increased slowly with an increase in copper concentration up to molar ratio of $\mathrm{Cu}(\mathrm{II}) / \mathrm{MVEMA}=1$ then increased sharply after $\mathrm{Cu}(\mathrm{II}) /$ MVEMA $>1$. These results were attributed to increasing copper concentration caused by the augmentation of formation of insoluble intermolecular complexes between copper ions and PMVEMA.

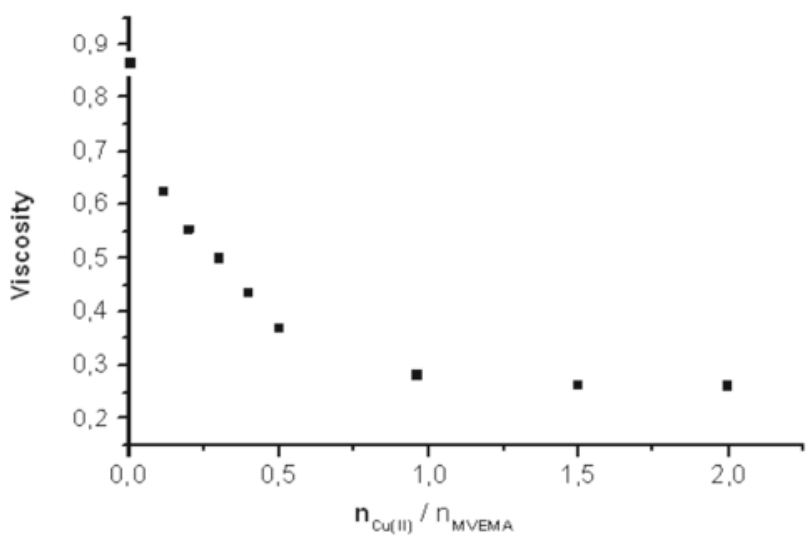

Figure 2. Viscosity values of the binary mixtures of PMVEMA prepared at different copper concentrations (intrinsic). The molar ratio of $\mathrm{Cu}(\mathrm{II}) / \mathrm{MVEMA}=0.1,0.2$, $0.3,0.4,0.5,1.0,1.5$ and 2.0 . The total volume of solution is $10 \mathrm{~mL}$. The $\mathrm{pH}$ of each solution equals to 7 . $\mathrm{C}_{\text {PMVEMA }}=3 \mathrm{~g} / \mathrm{L}$

Figure 2 indicates the relationship between the viscosity of binary solution of copper ion and the ratio of $\mathrm{n}_{\mathrm{Cu}(\mathrm{III})} /$ $\mathrm{n}_{\text {MVEMA }}$ at $\mathrm{pH}=7$. The viscosity of solution decreased with an increase in the molar ratio of copper ions to monomer unit (MVEMA) in phosphate buffer solution at $\mathrm{pH}=7$ (Fig. 2). The decrease in the viscosity of binary solution of $\mathrm{Cu}(\mathrm{II})$ and PMVEMA with increase in copper concentration is attributed to increasing copper concentration acting to the increase of the formation of insoluble complexes and after separation of these insoluble particles, the viscosity of solution decreased.

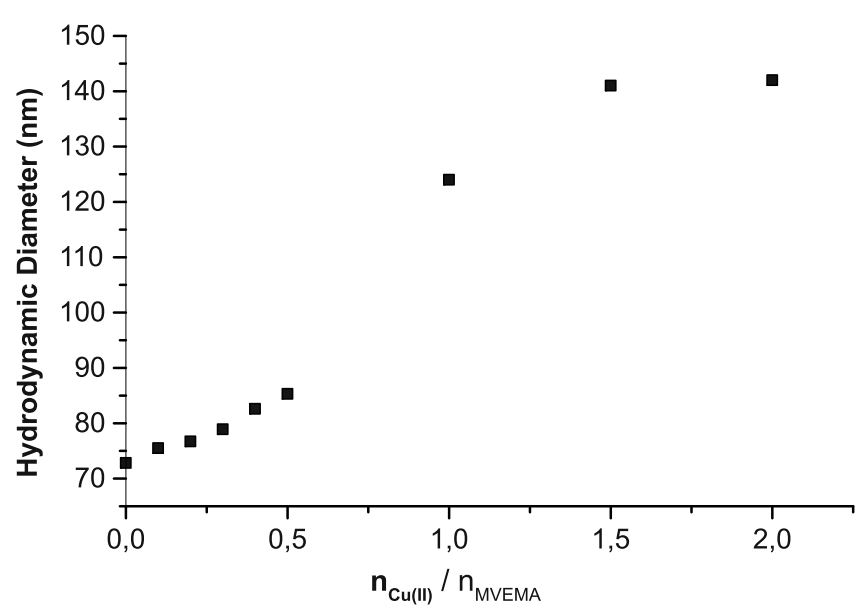

Figure 3. The dependence of hydrodynamic diameter of binary mixture of PMVEMA-Cu(II) prepared at different copper concentration (The molar ratio of $\mathrm{Cu}(\mathrm{II}) /$ MVEMA $=0.1,0.2,0.3,0.4,0.5,1.0,1.5$ and 2.0). The $\mathrm{pH}$ of each solution equals to 7 . The total volume of solution is $10 \mathrm{~mL}$. $\mathrm{C}_{\text {PMVEMA }}=3 \mathrm{~g} / \mathrm{L}$

The average particle size of soluble and insoluble complexes of binary mixtures of $\mathrm{Cu}(\mathrm{II})$-PMVEMA was determined by using DLS measurements depending on the molar ratios of copper ions to polymer (PMVEMA) (Fig. 3). Figure 3 illustrated, at the beginning of adding of copper ions to the binary mixture, average particle sizes of soluble and insoluble complexes started to be increased and reached at the ratio of $\mathrm{n}_{\mathrm{Cu}(\mathrm{II})} / \mathrm{n}_{\text {MVEMA }}=1$ with an increase in the copper concentration. This result indicates that insoluble complexes caused the augmentation of hydrodynamic diameters of particles due to formation of intermolecular complexation.

The dependence of zeta potential of binary mixture of $\mathrm{Cu}$ (II)-PMVEMA on the ratio of $\mathrm{n}_{\mathrm{Cu}(\mathrm{III}} / \mathrm{n}_{\mathrm{MVEMA}}$ is given in Figure 4. Zeta potential of binary mixture of

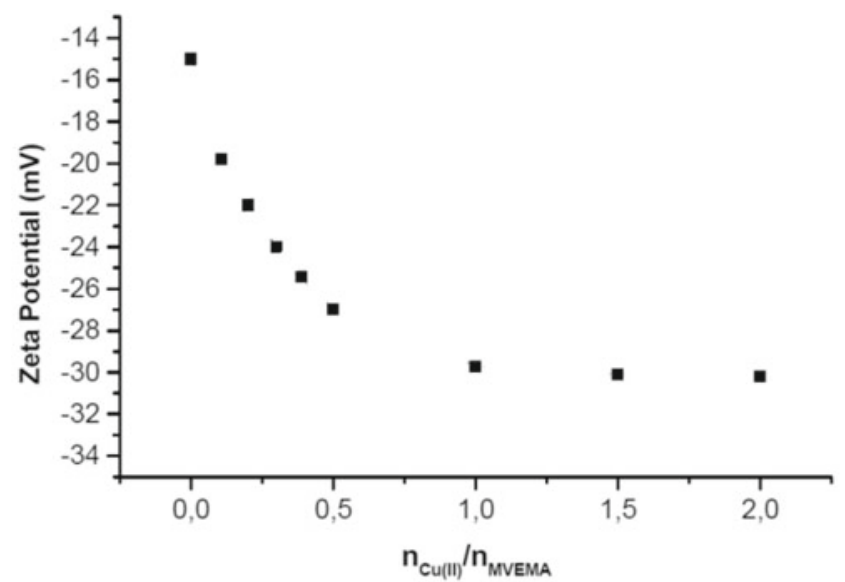

Figure 4. The effect of the ratios of $\mathrm{n}_{\mathrm{CU}(\mathrm{II})} / \mathrm{n}_{\mathrm{MVEMA}}$ on zeta potential of the solutions of binary mixtures of PMVEMA-Cu(II) prepared at phosphate buffer solution in $\mathrm{pH}=7$. The molar ratio of $\mathrm{Cu}(\mathrm{II}) / \mathrm{MVEMA}=0.1$, $0.2,0.3,0.4,0.5,1.0,1.5$ and 2.0. The total volume of solution is $10 \mathrm{~mL}$. $\mathrm{C}_{\text {PMVEMA }}=3 \mathrm{~g} / \mathrm{L}$ 


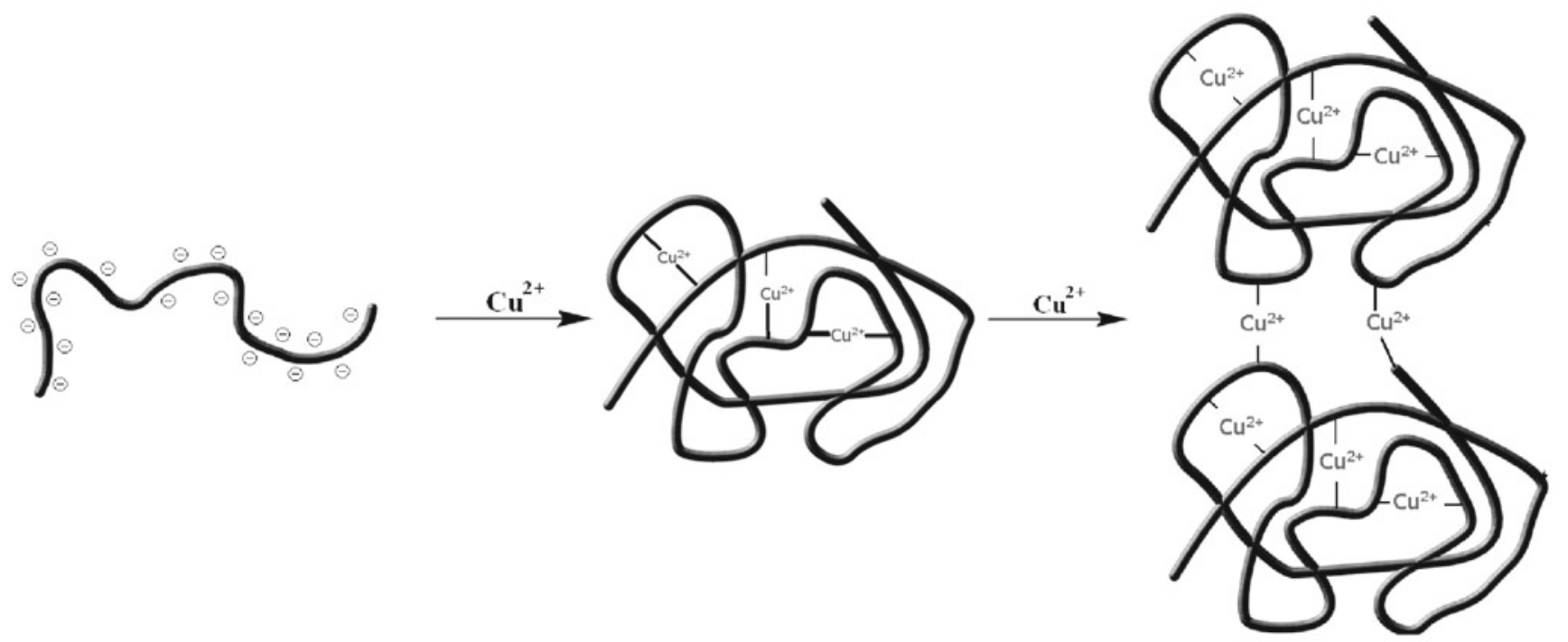

Scheme 1. Chemical structural model of binary complexes of $\mathrm{Cu}$ (II)-PMVEMA

$\mathrm{Cu}$ (II)-PMVEMA decreased with increasing copper concentration, reaching approximate minimum value at the molar ratio of $\mathrm{Cu}(\mathrm{II}) / \mathrm{MVEMA}=1$. The mechanism of formation of insoluble complexes of $\mathrm{Cu}(\mathrm{II})$-PMVEMA is illustrated in the Scheme 1.

\section{Formation of ternary polymer-metal-protein complexes}

The solutions of polymer-metal complexes of $\mathrm{Cu}(\mathrm{II})$ -PMVEMA were used to prepare the ternary complexes of PMVEMA-Cu(II)-BSA in phosphate buffer solution at $\mathrm{pH}=7$. These complexes were researched by spectrophotometric measurements.

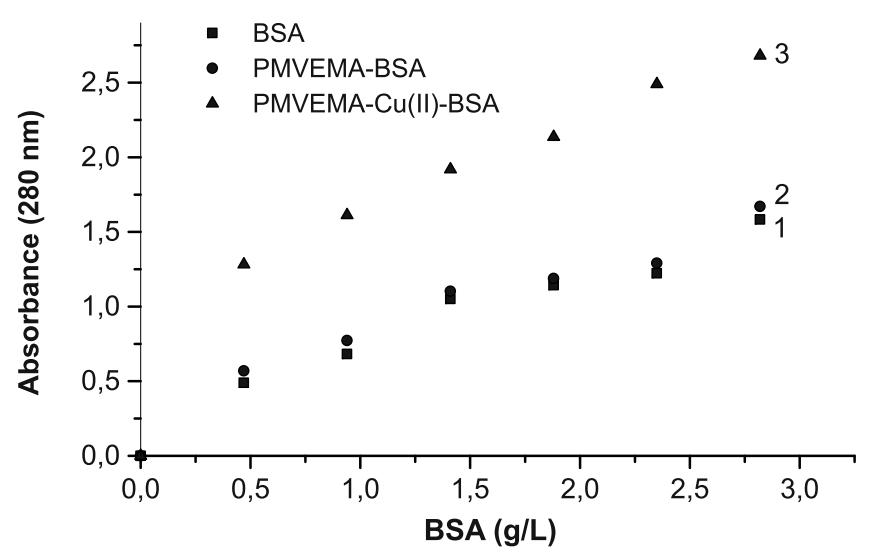

Figure 5. The dependence of optical density $\left(\mathrm{A}_{280}\right)$ on the BSA concentration for BSA solutions, the binary mixtures of PMVEMA-BSA and the ternary mixtures of PMVEMA-Cu(II)-BSA prepared at phosphate buffer solution at $\mathrm{pH}=7 . \mathrm{C}_{\text {PMVEMA }}=3 \mathrm{~g} / \mathrm{L}$, the molar ratio of $\mathrm{Cu}(\mathrm{II}) / \mathrm{MVEMA}=0.5$ and $\mathrm{n}_{\mathrm{BSA}} /$ $\mathrm{n}_{\text {PMVEMA }}=0.5,1.0,1.5,2.0,2.5$ and 3.0

The optical density $\left(\mathrm{A}_{280}\right)$ of the solutions of BSA, BSA-PMVEMA and BSA-Cu(II)-PMVEMA ( $\mathrm{n}_{\mathrm{BSA}} /$ $\mathrm{n}_{\text {PMVEMA }}=0.5,1.0,1.5,2.0,2.5$ and 3.0) were examined. Figure 5 shows the dependence of optical density $\left(\mathrm{A}_{280}\right)$ for the solution of BSA, PMVEMA-BSA and PMVEMA-Cu(II)-BSA on BSA concentration. Figure 5 indicates that the absorbance values at $280 \mathrm{~nm}$ shows an augmentation with increasing protein concentration in the system depending on free protein concentration and complex formation between polymer and protein in presence of copper ions. The value of $\mathrm{A}_{280}$ of the solutions of BSA and PMVEMA-BSA increased with increasing of BSA concentration (Fig. 5 curve 1 and 2), respectively. However, the slopes of these curves are almost of the same value, so there isn't any interaction between BSA and PMVEMA. But, when protein solutions $\left(\mathrm{n}_{\mathrm{BSA}} / \mathrm{n}_{\text {PMVEMA }}=0.5,1.0,1.5,2.0,2.5\right.$ and 3.0$)$ in phosphate buffer solution at $\mathrm{pH}=7$ were mixed with the solution of PMVEMA-Cu(II) (PMVEMA $=3 \mathrm{~g} / \mathrm{L}$, $\left.\mathrm{n}_{\mathrm{Cu}(\mathrm{II})} / \mathrm{n}_{\mathrm{MVEMA}}=0.5\right)$ at $\mathrm{pH}=7$, the absorbance value of $\mathrm{A}_{280}$ changed more with increasing of the concentration of BSA (Fig. 5, curve 3). These results indicate that protein can reacts with copper ions to form polymer and protein complexes (see scheme 2 for hypothetical chemical structure of ternary PMVEMA-Cu(II)-BSA complex).

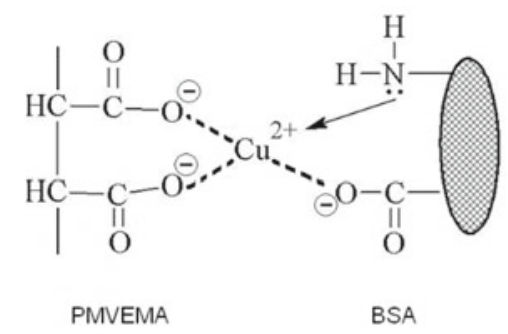

Scheme 2. The hypothetical chemical structure of ternary water soluble complex of PMVEMA-Cu(II)-BSA

The velocity of the formation of soluble and insoluble ternary complexes of PMVEMA-Cu(II)-BSA depends on what sequence BSA to PMVEMA-Cu(II) (PMC) or PMC to BSA is added.

In both cases, ternary complexes of PMVEMA with BSA in the presence of copper ions are formed depending on time. The effect of the method of preparation was given in Figure 6. The variation of absorbance at $280 \mathrm{~nm}$ versus time for two earlier method preparations, i.e., the BSA solutions were added to the PMC solutions and PMC solutions were added to the BSA solutions (Fig. 6) respectively. As can be seen from Figure 6, in both cases the $\mathrm{A}_{280}$ values increased with time and absorbance values reached an equilibrium at 300-350 min. Results reveal that when PMC solutions were added to the BSA solutions, the formation of ternary complexes between PMC and BSA was faster than the formation of ternary complexes between BSA and PMC when BSA solutions were added to PMC solutions. 


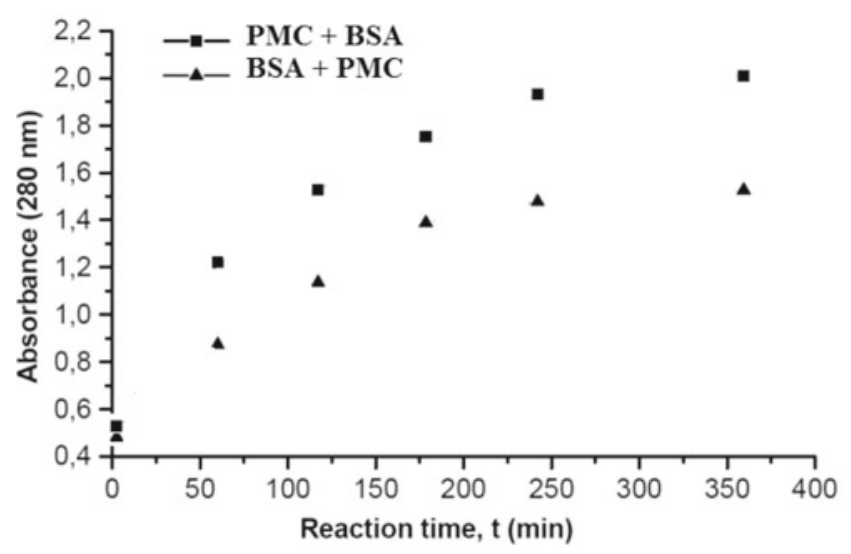

Figure 6. The velocity of the formation of soluble and insoluble ternary complexes of PMVEMA-Cu(II)-BSA depending on the order of addition (BSA to PMC (PMVEMA-Cu(II)) ( $\mathbf{\Delta})$ or PMC to BSA (ם). The $\mathrm{pH}$ of each solution containing phosphate buffer solution is 7. The total volume of solution is $10 \mathrm{~mL}$. $\mathrm{C}_{\text {PMVEMA }}=3 \mathrm{~g} / \mathrm{L}$

BSA contains two Trp residues. Trp has a wavelength of maximum absorption at $280 \mathrm{~nm}$ and emission peak that is solvatochromic ranging from 300 to $350 \mathrm{~nm}$ depending on the polarity of local environment. Hence, protein fluorescence could be used to examine the properties of the mixtures of protein-metal and protein-metal-polymer by measuring the values of the fluorescence parameters such as $I_{\max }, \lambda_{\text {max }}$, quantum yield and lifetime and others ${ }^{34,35,42}$.

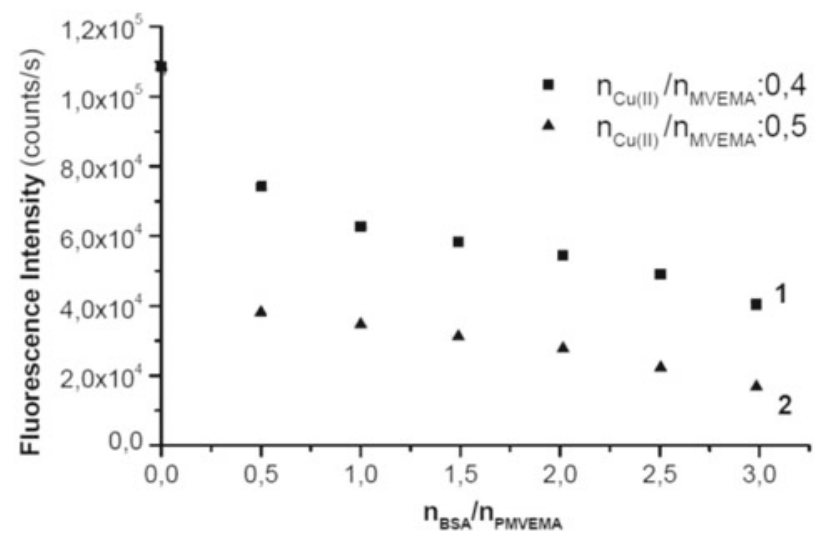

Figure 7. The relation between $\mathrm{I}_{\max }$ of ternary mixtures of PMVEMA-Cu(II)-BSA and molar ratios of BSA/ PMVEMA $\left(\mathrm{n}_{\mathrm{BSA}} / \mathrm{n}_{\text {PMVEMA }}=0.5,1.0,1.5,2.0,2.5\right.$ and 3.0) prepared at the molar ratios of $\mathrm{CU}(\mathrm{II}) /$ MVEMA $=0.4(\boldsymbol{\square})$ and $0.5(\boldsymbol{\Delta}) . \mathrm{C}_{\text {PMVEMA }}=3 \mathrm{~g} / \mathrm{L}$

The dependence of $\mathrm{I}_{\max }$ of fluorescence intensity of BSA with PMVEMA in the presence of different $\mathrm{Cu}(\mathrm{II})$ concentrations $\left(\mathrm{n}_{\mathrm{Cu}(\mathrm{II})} / \mathrm{n}_{\text {MVEMA }}=0.4\right.$ and 0.5$)$ in phosphate buffer solution at $\mathrm{pH}=7$ on the increase in BSA concentration was shown in Figure 7. It was observed that with augmentation in $\mathrm{Cu}(\mathrm{II})$ concentration, the intensity of emission maximum $\left(\mathrm{I}_{\max }\right)$ decreased due to quenching of Trp in BSA. Moreover, the increase in copper concentration leds to the formation of conformational changes and quenching effect. For this reason, in the case of the complex formation of PMVEMA with BSA in the presence of the $\mathrm{n}_{\mathrm{CU}(\mathrm{II})} / \mathrm{n}_{\mathrm{MVEMA}}=0.4$ (Fig. 7 , curve 1 ), the fluorescence intensity of ternary mixture of PMVEMA-Cu(II)-BSA is higher than that occurred in complex formation of PMVEMA with BSA in the presence of the $\mathrm{n}_{\mathrm{CU}(\mathrm{II})} / \mathrm{n}_{\text {MVEMA }}=0.5$ (Fig. 7, curve 2).

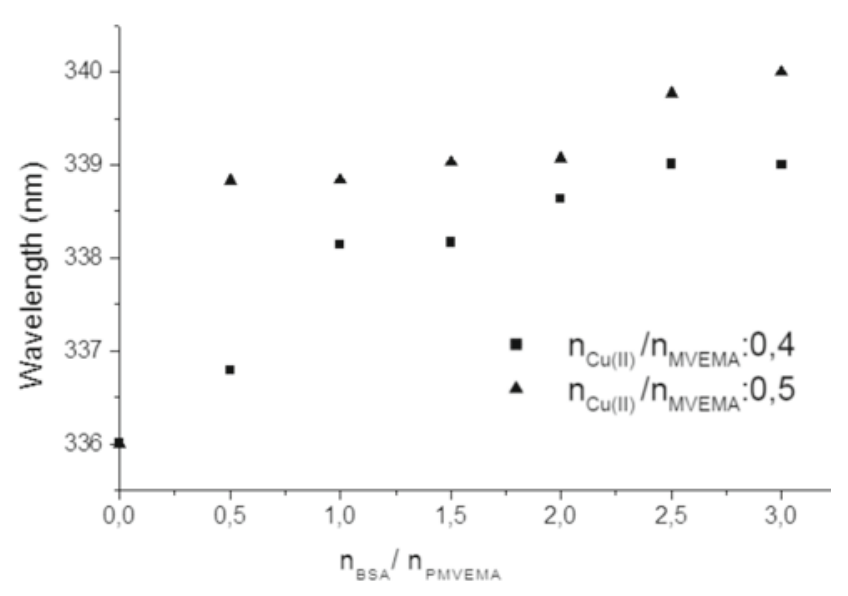

Figure 8. The effect of molar ratios of BSA/PMVEMA on the position of $\lambda_{\max }$ of ternary mixtures of PMVEMA-Cu(II)-BSA prepared at different copper concentrations $\left(\mathrm{n}_{\mathrm{Cu}(\mathrm{II})} / \mathrm{n}_{\mathrm{MVEMA}}=0.4(\boldsymbol{\Delta})\right.$ and $0.5(\boldsymbol{\square})$ ). $\mathrm{n}_{\text {BSA }} / \mathrm{n}_{\text {PMVEMA }}=0.5,1.0,1.5,2.0,2.5$ and 3.0. The $\mathrm{pH}$ of each solution containing phosphate buffer solution is 7 . The total volume of solution is $10 \mathrm{~mL}$. $\mathrm{C}_{\text {PMVEMA }}=3 \mathrm{~g} / \mathrm{L}$

Interaction between the values of $\lambda_{\max }$ in the fluorescence spectra of the ternary complexes of PMVEMA- $\mathrm{Cu}$ (II)-BSA and the ratios of $\mathrm{n}_{\mathrm{BSA}} / \mathrm{n}_{\text {PMVEMA }}$ was given in Figure 8 , indicating an increase in $\lambda_{\max }$ values as BSA concentration increased; on the other hand, decreased by augmentation of copper concentration. This phenomenon was described as red shift indication in previous studies ${ }^{2,3,25,42}$. Experimental results indicate that tryptophan of BSA is influenced from local environment resulting from interaction PMVEMA, BSA with copper ions. Therefore, tryptophan fluorescencing can be very sensitive in determining the conformational state of BSA because of the tryptophan residues. For this reason, the red shift indicates that the environment of Trp becomes more hydrophilic feature; and the interaction between Trp molecules of BSA and water increases with increasing maximum wavelength emission of ternary mixture of PMVEMA-Cu(II)-BSA as describe in previous studies ${ }^{25}$.

DLS measurements solutions, of pure BSA, PMVEMA and the mixtures of BSA with PMC at varied molar ratios of BSA/PMVEMA $=0.5,1.0,1.5,2.0,2.5$ and 3.0 in phosphate buffer solution at $\mathrm{pH}=7$ are shown in Figure 9. As made mention of Figure 9, hydrodynamic diameter of BSA and PMVEMA show peaks at 9.75 $\mathrm{nm}$ and $40.02 \mathrm{~nm}$, respectively. When BSA solution was added to PMC solution at the molar ratio of $\mathrm{Cu}(\mathrm{II})$ / MVEMA $=0.5$, a new peak having higher dynamic diameter was observed at $455.60 \mathrm{~nm}$ attributed to the formation of ternary complexes $\left(\mathrm{n}_{\mathrm{Cu}(\mathrm{II})} / \mathrm{n}_{\mathrm{MVEMA}}=0.5\right)$, supporting the formation of ternary complexes.

Zeta potentials of the solutions of the ternary mixtures BSA and PMC $\left(\mathrm{n}_{\mathrm{Cu}(\mathrm{II})} / \mathrm{n}_{\text {MVEMA }}=0.5\right)$ in phosphate buffer solution at $\mathrm{pH}=7$ were measured (Fig. 10). The zeta potentials of the solutions of BSA and PMVEMA have negative charges. This phenomenon prevents the formation of bond between BSA and PMVEMA. 
(a)
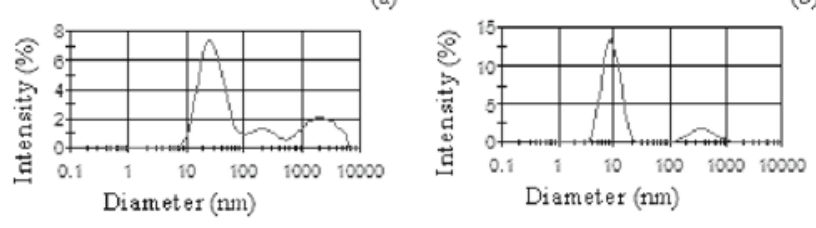

(c)

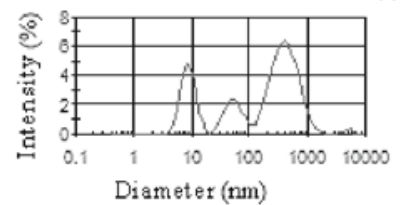

Figure 9. The relation between the intensities of solutions of PMVEMA (a), BSA (b) and ternary mixture of PMVEMA-Cu(II)-BSA $\left(\mathrm{n}_{\mathrm{Cu}(\mathrm{II})} / \mathrm{n}_{\text {MVEMA }}=0.5\right.$ and $\left.\mathrm{n}_{\text {BSA }} / \mathrm{n}_{\text {PMVEMA }}=3.0\right)(\mathrm{c})$ prepared at phosphate buffer solution at $\mathrm{pH}=7$. $\mathrm{C}_{\text {PMVEMA }}=3 \mathrm{~g} / \mathrm{L}$

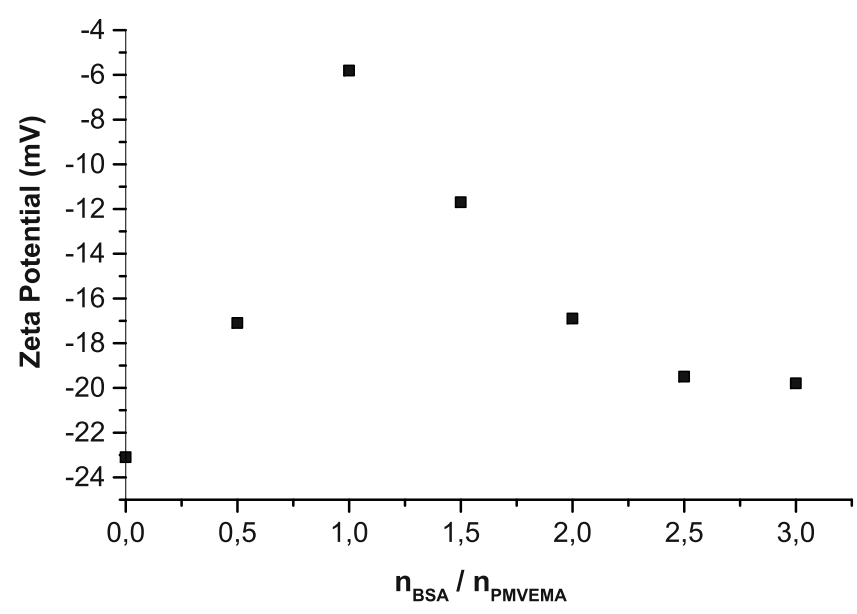

Figure 10. Zeta potentials of ternary mixtures of PMVEMA-Cu(II)-BSA containing various BSA concentrations $\left(\mathrm{n}_{\mathrm{BSA}} /\right.$ $\mathrm{n}_{\text {PMVEMA }}=0.5,1.0,1.5,2.0,2.5$ and 3.0) prepared at phosphate buffer solution at $\mathrm{pH}=7 . \mathrm{C}_{\text {PMVEMA }}=3 \mathrm{~g} / \mathrm{L}$

Divalent $\mathrm{Cu}(\mathrm{II})$ ions act as "fasteners" promoting the formation of ternary complexes. When BSA solution started to mix with PMC solutions, the zeta potential of solutions increased and reached a maximum value at the molar ratio of BSA/PMVEMA $=1.0$ in the presence of copper ions $\left(\mathrm{n}_{\mathrm{Cu}(\mathrm{II})} / \mathrm{n}_{\text {MVEMA }}=0.5\right)$. Increase in the $\mathrm{n}_{\mathrm{BSA}} /$ $\mathrm{n}_{\text {PMVEMA }}$ ratio caused a decrease in, the zeta potential of ternary BSA-Cu(II)-PMVEMA mixture. This indicates that solubility and stability of polycomplexes depend on the composition of PMVEMA, the molar ratio of BSA/ PMVEMA and $\mathrm{Cu}(\mathrm{II}) / \mathrm{MVEMA}^{3}$.

The solutions of PMVEMA $(0.15 \mathrm{~g} / \mathrm{L}), \mathrm{BSA}(0.15 \mathrm{~g} / \mathrm{L})$ and the ternary mixture of PMVEMA-Cu(II)-BSA were prepared in phosphate buffer solution at $\mathrm{pH}=7$. Each of prepared solutions was placed on the mica surface. The surface of mica coated with the solution of PMVEMA, BSA or ternary mixture of PMVEMA-Cu(II)-BSA was dried at room temperature.

Figure 11 shows the scanning images of PMVEMA (Fig. 11, a), BSA (Fig. 11, b) and ternary mixture of PMVEMA-Cu(II)-BSA (Fig. 11, c). As seen from figure 11 , when the structures of particle distributions in the scanning imagines of the solutions of PMVEMA (Fig. 11, a), BSA (Fig. 11, b) and ternary mixture of PMVEMA-Cu(II)-BSA (Fig. 11, c) prepared in phosphate

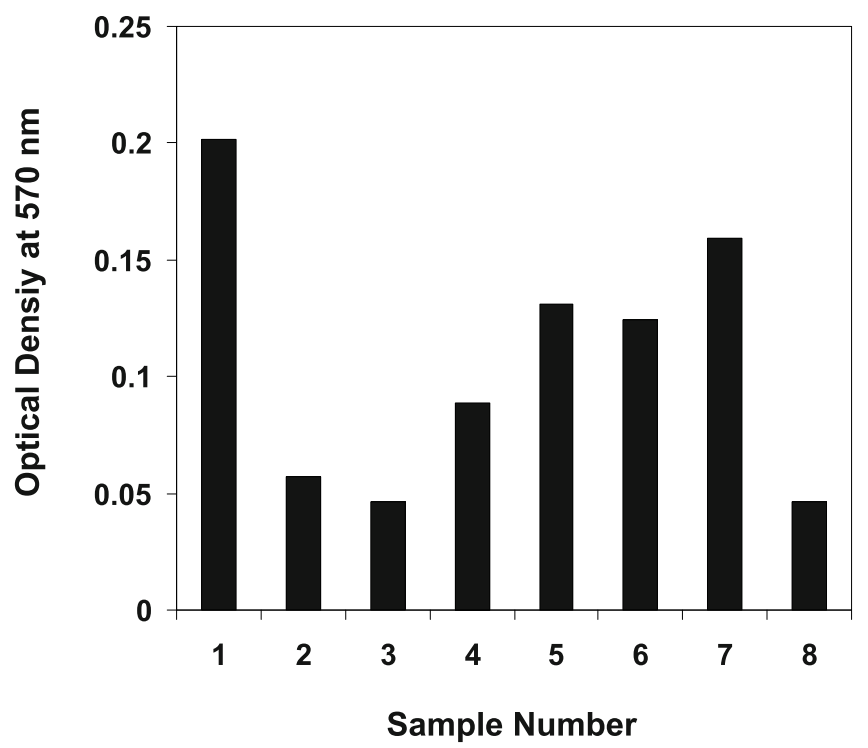

Figure 11. Scanning imagines of PMVEMA (a), BSA (b) and ternary mixture of PMVEMA-Cu(II)-BSA (c). $\mathrm{C}_{\text {PMVE- }}$ $\mathrm{MA}=0.15 \mathrm{~g} / \mathrm{L}, \mathrm{C}_{\mathrm{BSA}}=0.15 \mathrm{~g} / \mathrm{L}$ and $\mathrm{n}_{\mathrm{Cu}(\mathrm{II})} / \mathrm{n}_{\mathrm{MVEMA}}=0.5$

buffer solution at $\mathrm{pH}=7$ have been compared, it has been observed that more uniform structure of particles distribution has appeared in the scanning imagine of the solution of ternary mixture of PMVEMA-Cu(II)-BSA (Fig. 11, c).

The optical density of reference sample was given as Figure 12, sample 1. As can be seen from Figure 12, it was observed that the toxicity of the binary mixture of PMVEMA-Cu(II) $\left(\mathrm{n}_{\mathrm{Cu}(\mathrm{II})} / \mathrm{n}_{\text {MVEMA }}=0.5\right)($ Fig. 12 , sample 3) was higher than those of the solution PMVEMA (Fig. 12 sample 2) and PMVEMA-Cu(II)-BSA ( $\mathrm{n}_{\mathrm{Cu}(\mathrm{II})} /$ $\mathrm{n}_{\text {MVEMA }}=0.5$ and $\mathrm{n}_{\text {BSA }} / \mathrm{n}_{\text {PMVEMA }}=2.0$ ) (Fig. 12 sample 4). The efficiency of toxicities of these compounds has been in the order of PMVEMA-Cu(II)>PMVEMA$>$ PMVEMA-Cu(II)-BSA. When the toxicities of the solutions and mixtures of PMVEMA and PAA with/ without BSA in the presence of copper ions were compared, the toxicities of the solution PMVEMA and PMVEMA-Cu(II) and PMVEMA-Cu(II)-BSA (Fig. 12, samples 2-4) were higher than those of the solution of PAA and PAA-Cu(II) $\left(\mathrm{n}_{\mathrm{Cu}(\mathrm{II})} / \mathrm{n}_{\mathrm{AA}}=0.4\right)$ and PAA-Cu(II)-BSA $\left(\mathrm{n}_{\mathrm{Cu}(\mathrm{II})} / \mathrm{n}_{\mathrm{AA}}=0.4\right.$ and $\left.\mathrm{n}_{\mathrm{BSA}} / \mathrm{n}_{\mathrm{PAA}}=1.0\right)$ (Fig. 12, samples 5-7). When the toxicities of solutions of the ternary mixture of PAA-Cu(II)-BSA, containing two different BSA concentrations were examined, the toxicity of the ternary mixture of PAA-Cu(II)-BSA prepared at the molar ratio of protein/polymer $=1.0$ (Figure 12 sample 7) is lower than that of the ternary mixture of PAA-Cu(II)-BSA (Figure 12 sample 8) prepared at the molar ratio of protein/polymer $=2.00^{43}$. These results indicate that the toxicities of solutions of polymer and mixtures of polymer-metal and polymer-metal-protein depend on the nature of pure components and the ratio of components in mixtures.

\section{CONCLUSIONS}

The binary and ternary complex formations of PMVEMA with copper ions and PMVEMA with BSA in the presence of copper ions in phosphate buffer solution at $\mathrm{pH}=7$ have been investigated by using UV-visible, 
a)

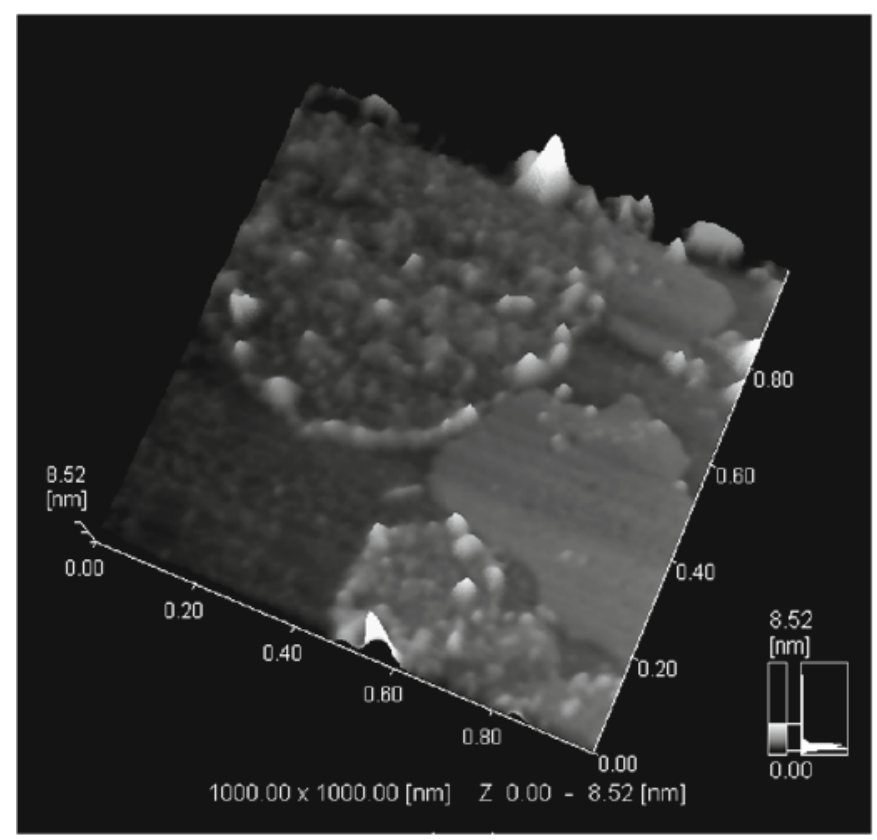

b)

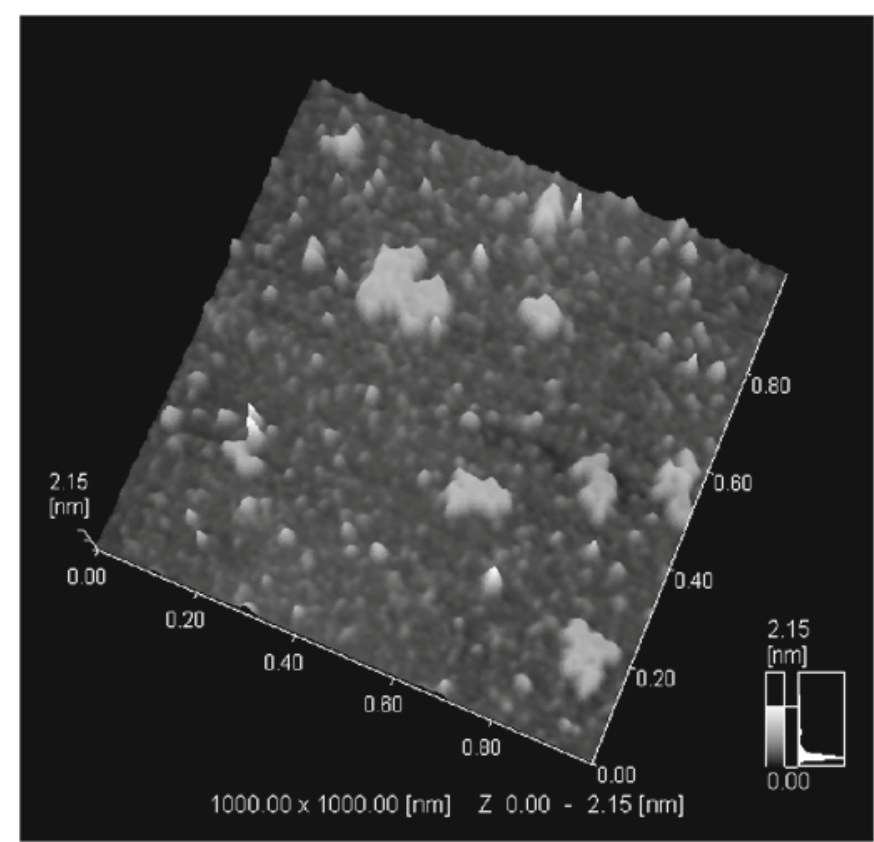

c)

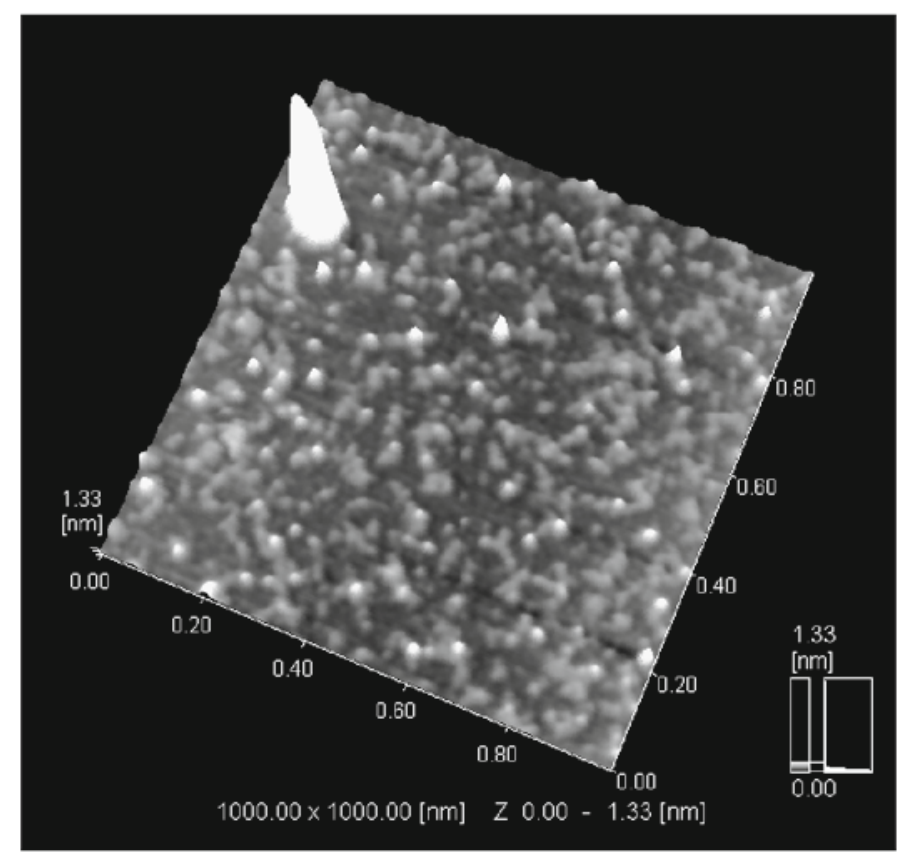

Figure 12. The toxicities of pure water (1) and the solutions of PMVEMA (2), binary mixture of PMVEMA-Cu(II) (nCu(II)/nMVEMA $=0.5)$ (3), ternary mixtures of PMVEMA-Cu(II)-BSA $\left(\mathrm{n}_{\mathrm{Cu}(\mathrm{II})} / \mathrm{n}_{\text {MVEMA }}=0.5\right.$ and $\left.\mathrm{n}_{\mathrm{BSA}} / \mathrm{n}_{\text {PMVEMA }}=2.0\right)$ (4), PAA (5), binary mixture of PAA-Cu(II) $\left(\mathrm{n}_{\mathrm{Cu}(\mathrm{II})} / \mathrm{n}_{\mathrm{PAA}}=0.4\right)(6)$ and ternary mixtures of PAA-Cu(II)-BSA prepared at different BSA concentrations $\left(\mathrm{n}_{\mathrm{Cu}(\mathrm{II})} /\right.$ $\mathrm{n}_{\text {PAA }}=0.4, \mathrm{n}_{\mathrm{BSA}} / \mathrm{n}_{\text {PMVEMA }}=1.0(7)$ and $\left.2.0(8)\right) . \mathrm{C}_{\text {PMVEMA }}=3 \mathrm{~g} / \mathrm{L}$

fluorescence, DLS and AFM measurements. UV-visible, gravimetric and DLS measurements indicated that the addition of different amount of copper ions to PMVEMA gives homogeneous solutions at phosphate buffer solution at $\mathrm{pH}=7$. It was observed that insoluble particles started to occur after the molar ratio of copper ions to methyl vinyl ether maleic anhydride equals to 0.5 , reaching a maximum value at the molar ratio of $\mathrm{Cu}(\mathrm{II}) / \mathrm{MVEMA}=1$. When the formations of ternary complexes of PMVEMA-Cu(II)-BSA were examined by UV-visible measurements, the values of $\mathrm{A}_{280}$ of the solution of BSA and PMVEMA-BSA increased with BSA concentration. However, the slope of the curves had almost the same value. Results suggest no interaction between BSA and PMVEMA; however, for BSA solutions mixed with the solutions of PMVEMA-Cu(II), the absorbance $\left(\mathrm{A}_{280}\right)$ increased more with increasing BSA concentration. When fluorescence measurements were applied to examine the formation of ternary complexes of PMVEMA-Cu(II)-BSA, the intensity of $\mathrm{I}_{\max }$ decreased with augmentation in $\mathrm{Cu}$ (II) concentration due to quenching of Trp in BSA. The $\lambda_{\max }$ in the fluorescence measurements of ternary complexes of PMVEMA-Cu(II)-BSA increased with increasing BSA concentration 
but decreased by augmentation of copper concentration. This finding showed as red shift indication in literatu$\mathrm{re}^{2,3,25,42}$ indicates that Trp becomes more hydrophilic feature and the interaction between Trp molecules of BSA and water increases with increasing maximum wavelength emission of PMVEMA-Cu(II)-BSA. The scanning image of the ternary mixture of PMVEMA- $\mathrm{Cu}$ (II)-BSA measured by AFM technique showed a uniform structure at nano-scale. The toxicity of binary mixture of PMVEMA-Cu(II) $\left(\mathrm{n}_{\mathrm{Cu}(\mathrm{II})} / \mathrm{n}_{\text {MVEMA }}=0.5\right)$ was higher than those of the solution of PMVEMA and ternary mixture of PMVEMA-Cu(II)-BSA( $\mathrm{n}_{\mathrm{Cu}(\mathrm{II})} / \mathrm{n}_{\mathrm{MVE}}$ $\mathrm{MA}=0.5$ and $\left.\mathrm{n}_{\mathrm{BSA}} / \mathrm{n}_{\text {PMVEMA }}=2.0\right)$. Toxicity efficiencies of these compounds have been ordered as PMVEMA-Cu(II) > PMVEMA > PMVEMA-Cu(II)-BSA. Not only ternary complexes were lower than binary complexes but also lower than pure polymer. When solution toxicities of mixtures of PMVEMA and PAA with/without BSA in the presence of copper ions were compared, the toxicities of the solution of PMVEMA, PMVEMA-Cu(II) and PMVEMA-Cu(II)-BSA increased in comparison to solutions of PAA, PAA-Cu(II) $\left(\mathrm{n}_{\mathrm{Cu}(\mathrm{II})} / \mathrm{n}_{\mathrm{AA}}=0.4\right)$ and PAA-Cu(II)-BSA $\left(\mathrm{n}_{\mathrm{Cu}(\mathrm{II})} / \mathrm{n}_{\mathrm{AA}}=0.4\right.$ and $\left.\mathrm{n}_{\mathrm{BSA}} / \mathrm{n}_{\mathrm{PAA}}=1.0\right)$. When the toxicity of the ternary mixtures, containing two different BSA concentrations were compared, the toxicity of the ternary mixture of PAA-Cu(II)-BSA prepared at the molar ratio of protein/polymer $=1.0$ (Fig. 12, sample 7) was lower than the ternary mixture of PAA-Cu(II)-BSA (Fig. 12, sample 8) prepared at the molar ratio of protein/polymer $=2.0$, revealing the contrast between PMVEMA with PAA polymers. Additionally the toxicities of solutions of polymer, polymer-metal and polymer-metal-protein mixtures depend on the nature of pure components and the ratio of components in mixtures. Most significant finding was its use in biotechnological applications, such as antitumor agent and new type of synthetic immunogens.

\section{ACKNOWLEDGMENT}

In the loving memory of Founder Head of Yildı Technical University Bioengineering Department, precious man of science, Prof. Dr. M.I. Mustafaev. This research was supported by a grant from Republic of Turkey Prime Ministry State Planning Organization (Project Number 25-DPT-07-04-01).

\section{ABBREVIATION}

$\begin{array}{ll}\text { BSA } & - \text { Bovine serum albumin } \\ \text { PMVEMA } & - \text { Poly(methyl vinyl ether-co-maleic } \\ & \text { anhydride) } \\ \text { PE } & - \text { Polyelectrolyte } \\ \text { PMC } & - \text { Polymer-metal complexes } \\ \text { M } & - \text { Metal } \\ \text { MVEMA } & - \text { Methyl vinyl ether maleic anhydride } \\ \text { pI } & - \text { Isoelectric points } \\ \text { DLS } & - \text { Dynamic light scattering } \\ \text { AFM } & - \text { Atomic force microscope } \\ \text { PAA } & - \text { Poly(acrylic acid) } \\ \text { MTT } & -3-(4,5-D i m e t h y l t h i a z o l-2-y l)-2,5-d i p h e n- \\ & - \text { yltetrazolium bromide, a yellow tet- } \\ & \text { razole }\end{array}$

\section{LITERATURE CITED}

1. Mustafaev, M.I. (1996). Biyopolimerler (Biopolymers), Kocaeli, Turkey: TUBITAK Publishers.

2. Karahan, M., Mustafaeva, Z. \& Özeroğlu, C. (2010). Investigation of Ternary Complex Formations of Polyacrylic Acid with Bovine Serum Albumin in the Presence of Metal Ions by Fluorescence and Dynamic Light Scattering Measurements. Protein J. 29, 336-342. DOI: 10.1007/s10930-010-9257-1.

3. Karahan, M. (2009). Development Of Functional Biopolymer Systems Containing Metal. Unpublished doctoral dissertation, Yildiz Technical University, Turkey.

4. Mustafaev, M.I. \& Norimov, A.S. (1990). Polymer-Metal Complexes of Protein Antigens- New Highly Effective Immunogens. Biomed. Sci. 1, 274-278.

5. Mustafaev, M.I., Yücel, F., Cirakoglu, B. \& Bermek, E. (1996). Immune Response to Progesterone Involved in $\mathrm{Cu}^{2+}$ -mediated Polyanion-Protein Complex-Antigen Specificity and Affinity of Hybridoma clones. Polymer-Metal Complexes of Protein Antigens- New Highly Effective Immunogens. Immunol. Lett. 52, 63-68.

6. Dincer, B., Mustafaev, M.I. \& Bayülken, S. (1997). High-performance liquid chromatography study of water-soluble ternary polyacrylamide-metal-protein complexes. J Appl. Polym. Sci. 65, 37-40.

7. Shoukry, M.M., Khairy, E.M. \& El-Sherif, A.A. (2002). Ternary complexes involving copper(II) and amino acids, peptides and DNA constituents. The kinetics of hydrolysis of a-amino acid esters. Transit. Metal Chem. 27, 656-664. DOI: 10.1023/A:1019831618658.

8. Etaiw, S.E.D.H., Sultan, A.S. \& El-Bendary, M.M. (2011). In vitro and in vivo antitumor activity of novel 3D-organotin supramolecular coordination polymers based on $\mathrm{CuCN}$ and pyridine bases. J. Organomet. Chem. 696, 1668-1676. DOI: 10.1016/j.jorganchem. 2011.02.003.

9. Andrianov, A.K., Marin, A. \& DeCollibus, D.P. (2011). Microneedles with intrinsic immunoadjuvant properties: microfabrication, protein stability, and modulated release. Pharm. Res. 28, 58-65. DOI: 10.1007/s11095-010-0133-7.

10. Ding, N.W., Lin, W.H., Sun, W.L. \& Shen, Z.Q. (2011). A novel hyperbranched aromatic polyamide containing bithiazole: synthesis, metal complexation and magnetic properties. Sci. China-Chem. 54(2), 320-325. DOI: 10.1007/s11426-010-4211-9.

11. Zhao, X.Z., Jiang, T., Wang, L., Yang, H., Zhang, S. \& Zhou, P. (2010). Interaction of curcumin with $\mathrm{Zn}$ (II) and $\mathrm{Cu}$ (II) ions based on experiment and theoretical calculation. $J$. Mol. Struct. 1(3), 316-325. DOI: 10.1016/j.molstruc.2010.09.049.

12. Kendirch, M.J., May, M.T., Philshica, M.J. \& Dobinson, K.D. (1992). Metal in biological systems, New York, Ellis Harwood.

13. Ali, M.M., Frei, E., Straubb, J., Breuerb, A. \& Wiesslerb, M. (2002). Induction of metallothionein by zinc protects from daunorubicin toxicity in rats. Toxicology 179, 85-93. DOI: 10.1016/S0300-483X(02)00322-0.

14. Wang, R.M., He, N.P., Song, P.F., He, Y.F., Ding, L. \& Lei, Z. (2009). Preparation of low-molecular-weight chitosan derivative zinc complexes and their effect on the growth of liver cancer cells in vitro. Pure Appl. Chem. 81(12), 2397-2405. DOI: 10.1351/PAC-CON-08-11-15.

15. Mustafaev, M.I., Norimov, A.Sh. \& Petrov, R.V. (1992). Sintheticeskiye immunomodulytari (Synthetic Immunomodulators). Moskova, Nauka.

16. Mustafaev, M. (2004). Functionally Biopolymer Systems. Sigma, J. Engineer. Natur. Sci. 4, 1-200.

17. Akkiliç, N., Mustafaeva, Z. \& Mustafaev, M. (2007). High performance liquid chromatography study of water-soluble complexes and covalent conjugates of polyacrylic acid with bovine serum albumin. J. Appl. Polym. Sci. 105, 3108-3120. DOI: 10.1002/app. 26366. 
18. Topuzogulları, M., Cimen, N.S., Mustafaeva, Z. \& Mustafaev, M. (2007). Molecular-weight distribution and structural transformation in water-soluble complexes of poly(acrylic acid) and bovine serum albumin. Eur. Polym. J. 43, 2935-2946. DOI: 10.1186/1423-0127-20-35.

19. Nilsson, K.P.R., Herland, A., Hammarstrom, P. \& Inganas, O. (2005). Conjugated polyelectrolytes: Conformation-sensitive optical probes for detection of arnyloid fibril forrnation. Biochem. 44, 3718-3724. DOI: 10.1021/bi047402u.

20. Xian, W.J., Tang, J.X., Janmey, P.A. \& Braunlin, W.H. (1999). The polyelectrolyte behavior of actin filaments: A Mg-25 NMR study. Biochem. 38, 7219-7226, DOI: 10.1021/bi982301f.

21. Sotiropoulou, M., Bokias, G. \& Staikos, G. (2005). Water-soluble complexes through coulombic interactions between bovine serum albumin and anionic polyelectrolytes grafted with hydrophilic nonionic side chains. Biomacromolecules 6(4), 1835-1838. DOI: 10.1021/bm050061v.

22. Kabanov, V.A. (2004). From synthetic polyelectrolytes to polymer subunit vaccines. Pure Appl. Chem. 76 (9), 1659-1677.

23. Nandakumar, K.S., Muthukkaruppan, V.R. (1999). Influence of Immunopotentiators on the Antiporin Immunoglobulin G Subclass: Distribution and Protective Immunity Against Murine Salmonellosis. Scand. J. Immunol. 50(2), 188-194. DOI: 10.1046/j.1365-3083. 1999.00576.x.

24. Karahan, M., Tuğlu, S. \& Mustafaeva, Z. (2012). Synthesis of microwave-assisted poly(methyl vinyl ether-co-maleic anhydride)-bovine serum albumin bioconjugates. Artif. Cells. Blood Substit. Biotech. 40(6), 363-368. DOI: 10.3109/10731199.2012.678942.

25. Filenko, A., Demchenko, M., Mustafaeva, Z., Yoshihito, O. \& Mustafaev, M.I. (2001). Fluorescens Study of $\mathrm{Cu}^{2+}$-Induced Interaction Between Albumin and Anionic Polyelectrolytes. Biomacromolecules 2(1), 270-277. DOI: 10.1021/bm000111q.

26. Mustafaev, M.I., Saraç, A.S. \& Erkol, A.Y. (1996). Effects of $\mathrm{Cu}^{2+}$ on Stability and Composition of Water Soluble Ternary Polyacrylic Acid-Cu ${ }^{2+}$-Protein Complexes Against Radiation Damage. Polymer Bulletin 36(5), 623-627.

27. Mustafaev, M.I., Yucel, F., Ozturk, S., Çirakoglu, B. \& Bermek, E. (1996). $\mathrm{Cu}^{2+}$-mediated Complex Formation Between Polyacrylic Acid (PAA) and Bovine Serum Albumin. J. Immunol. Methods 197(1-2), 31-37. DOI:10.1016/0022-1759(96)00107-X.

28. Karahan, M., Mustafaeva, Z. \& Ozer, H. (2007). Polysaccharide-protein Covalent Conjugates and Ternary Metal Complexes. Asian J. Chem. 19, 1837-1845.

29. Hilgers, L.A. Th., Nicolas, I., Lejeune, G., Dewil, E., Strebelle, M. \& Boon, B. (1998). Alkyl-esters of polyacrylic acid as vaccine adjuvants. Vaccine 16(16), 1575-1581. DOI: 10.1016/S0264-410X(98)00047-4.

30. Kennedy, Y.F. (1979). The tate and lyle carbohydrate chemistry award lecture. transition-metal oxide chelates of carbohydrate-directed macromolecules. Chem. Soc. Rev. 8, 221-228.

31. Sarkar, B. \& Wigfield, Y. (1968). Evidence for albumin$\mathrm{Cu}(\mathrm{II})$-amino acid ternary complex. Can. J. Biochem. 46, 601-607.

32. Zeng, W., Wang, L., Lin, S., Liu, S., Beuerman, R. \& Cao, D. (2011). Fluorescence enhancement of cationic diacetylene-contained polyelectrolyte by anions and cations and application for sensitive and selective detection of $\mathrm{Hg}^{(2+)} . J$. Polym. Sci. B-Polym. Phys. 49(23), 1690-1694. DOI: 10.1002/ polb.22362.

33. Wang, Y., Dong, J., Liu, C., Bao, B., Wang, L., Zhan, X., Yang, H. \& Wang, G. (2011). Fluorescence study of interaction between an anionic conjugated polyelectrolyte and bovine serum albumin. Polym. Bull. 67, 1907-1915, DOI: 10.1007/ s00289-011-0577-x.

34. Burstein, E.A., Vedenkina, N.S. \& Ivkova, M.N. (1973). Fluorescence and the location of tryptophan residues in protein molecules. Photochem. Photobiol. 18(4), 263-279. DOI: 10.1111/j.1751-1097.1973.tb06422.x.
35. Peters, T. (1996). All about albumin: biochemistry, genetics and medical applications. San Diego, Academic Press.

36. Douglas, J.T., Marilyn, P.W., Anthony, S.Q., Jacob, H.R., Edwin, G.B. \& Burton, E.S. (2008). Imaging Aspects of Cardiovascular Disease at the Cell and Molecular Level. Histochem. Cell. Biol. 130, 235-245. DOI: 10.1007/s00418-008-0444-5.

37. Nuno, C.S. \& Miguel, A.R.B.C. (2004). An Overview of the Biophysical Applications of Atomic Force Microscopy. Biophys. Chem. 107(2), 133-149. DOI: 10.1016/ j.bpc. 2003.09.001.

38. Miyagi, A., Ando, T. \& Lyubchenko, Y.L. (2011). Dynamics of Nucleosomes Assessed with Time-Lapse High-Speed Atomic Force Microscopy. Biochemistry 50, 7901-7908. DOI: 10.1021/bi200946z.

39. Cui, Y., Oh, Y.J., Lim, J., Youn, M., Lee, I., Pak, H.K., Park, W., Jo, W. \& Park, S. (2012). AFM study of the differential inhibitory effects of the green tea polyphenol (-)-epigallocatechin-3-gallate (EGCG) against Gram-positive and Gram-negative bacteria. Food Microbiol. 29(1), 80-87. DOI: 10.1016/j.fm.2011.08.019.

40. Liu, Y.F., Han, F.F., Xie, Y.G. \& Wang, Y.Z. (2011). Comparative antimicrobial activity and mechanism of action of bovine lactoferricin-derived synthetic peptides. Biometals 24(6), 1069-1078. DOI: 10.1007/s10534-011-9465-y.

41. Elter, P., Lange, R. \& Beck, U. (2012). Atomic force microscopy studies of the influence of convex and concave nanostructures on the adsorption of fibronectin. Coll. Surf. B-Biointer. 89, 139-146. DOI: 10.1016/j.colsurfb.2011.09.021.

42. Lakowich, J.R. (1986). Principles of fluorescence spectroscopy. New York, Plenum Press.

43. Karahan, M., Mustafaeva, Z., Çakır Koç, R., Bağırova, M., Allahverdiyev, A. (2014). Investigation of Metal-Polyelectrolyte complexes Toxicity. Toxic. Ind. Heal. 30(4), 384-389. DOI: $10.1177 / 0748233712457446$. 